\title{
Retraction Note: Cental macular thickness in patients with type 2 diabetes mellitus without clinical retinopathy
}

\author{
Mehmet Demir, Ersin Oba, Burcu Dirim, Erhan Ozdal and Efe Can
}

The corresponding author submitted this article [1] to the Journal of Ophthalmology although it was under review by BMC Ophthalmology. The article was subsequently accepted and published by the Journal of Ophthalmology [2] and then by BMC Ophthalmology [1]. As it has been brought to the attention of the Editor that duplicate submission and publication have taken place, the Editor has made the decision to retract the article published in $B M C$ Ophthalmology [1].

Received: 16 September 2015 Accepted: 16 September 2015

Published online: 16 November 2015

\section{References}

1. Demir M, Oba E, Dirim B, Ozdal E, Can E. Central macular thickness in patients with type 2 diabetes mellitus without clinical retinopathy. BMC Ophthalmol. 2013;13:11.

2. Demir M, Dirim B, Acar Z, Yilmaz M, Sendul Y. Central macular thickness in patients with type 2 diabetes mellitus without clinical retinopathy. J Ophthalmol. 2013;2013:767931.

\footnotetext{
* Correspondence: drmehmetfe@hotmail.com

Sisli Etfal Training and Research Hospital, Eye Clinic, Karayolları Mah, Abdi ipekci bulvarı. N0:32 Avrupa tem konutları 28. Blok. Daire:14. 34250 GOP, Sisli, Istanbul 34400, Turkey

Submit your next manuscript to BioMed Central and take full advantage of:

- Convenient online submission

- Thorough peer review

- No space constraints or color figure charges

- Immediate publication on acceptance

- Inclusion in PubMed, CAS, Scopus and Google Scholar

- Research which is freely available for redistribution 